Int. J. Dev. Biol. 64: 397-407 (2020)

https://doi.org/10.1387/ijdb.200020dr

\title{
Branching morphogenesis - historical first evidences
}

\author{
DOMENICO RIBATTI*,1 and DIEGO GUIDOLIN² \\ ${ }^{1}$ Department of Basic Medical Sciences, Neurosciences and Sensory Organs, University of Bari Medical School, Bari \\ and ${ }^{2}$ Department of Neuroscience, Section of Anatomy, University of Padova, Padova, Italy
}

\begin{abstract}
Branching morphogenesis, the creation of branched structures in the body, is a key feature of animal and plant development. It requires the coordinated interplay of multiple types of epithelial cells with the surrounding extracellular matrix. Cell migration, proliferation, and extracellular matrix dynamics have different roles in driving budding in different organs. This historical review article summarizes the first founding literature data concerning branching morphogenesis occurring in kidney, lung, vascular system, mammary glands and neurons.
\end{abstract}

KEY WORDS: branching, developmental biology, epithelial cell, extracellular matrix, morphogenesis

\section{Introduction}

A variety of cellular processes, including differential growth, cell invasion, epithelial folding and matrix-driven branching, can contribute to branching morphogenesis in different contexts(Varner and Nelson, 2014). Different epithelia, such as those of the thyroid follicles, kidney tubules, and the branching ducts in the lung and exocrine glands, acquire diverse forms correlated to their specific functions. The development of most glandular organs begins with the invagination of an existing epithelial sheet into the underlying mesenchyme (Hogan and Kolodziej, 2002). The primary bud thus generated subsequently undergoes a series of morphogenetic events that culminate in the formation of branching tubes (excretory ducts) and hollow spheres (follicles, alveoli, acini).

Tubules can arise through two main mechanisms: the invagination of cells from an epithelial sheet, as occurs in the formation of the neural tube or through the organization of initially un-polarized cells into cord-like structures that invade the surrounding mesenchyme, forming branched, hollow tubules lined by polarized cells (Hogan and Kolodziej, 2002). The formation of branching tubes from initial unbranched epithelial buds occurs in the development of many organs, including the pancreas, liver, mammary gland, lung, and kidney (Affolter et al., 2003, Lubarsky and Krasnow, 2003).

The development of many branched organs, including the lung, kidney, and salivary glands, depends on differential rates of cell proliferation (Goldin, 1980). Elevated levels of cell proliferation have been observed in nascent epithelial buds in response to growth factor expression in the neighboring mesenchyme. Local stimulation of epithelial cell proliferation is involved in the formation of new branches (Ettensohn, 1985). Elevated proliferation was localized to the branch tips and if growth factor-loaded beads were embedded onto the gel adjacent to mesenchyme-free explants, new epithelial branches extended toward the local source of growth factors (Park et al., 1998).

All organs consist of an epithelium and a mesenchyme (Grobstein, 1953, 1954, 1967). Epithelium is able to induce differentiation of the mesenchyme and vice-versa, and play an instructive role mediated by differential activation of genes in responding epithelial cells. Interactions between epithelium and mesenchyme are mediated by soluble factors, through direct cell-cell contact, as occurs during mammary gland development (Sakakura, 1991) and are under the influence of the extracellular matrix (ECM) (Grobstein, 1954), which changes its organization and adhesive properties (Ekblom, 1981, Ekblom et al., 1980) and by diffusion of soluble factors.

Using developing mouse salivary glands, Grobstein (Grobstein, 1954) demonstrated that isolated epithelial explants fail to branch

\footnotetext{
Abbreviations used in this paper: $\mathrm{bFGF}$, basic fibroblast growth factor; BMP, bone morphogenetic protein; Bnl, branchless; BARW, branching and annihilating random walks; EGF, epidermal growth factor; ECM, extracellular matrix; FGF, fibroblast growth factor; FCS, foetal calf serum; GDNF, glial-derived neurotrophic factor; GFAP, glial fibrillary acid protein; GAG, glycosaminoglycan; HGF, hepatocyte growth factor; MDCK, Madin-Darby canine kidney; MMP, matrix metalloproteinase; NSC, neural stem cell; PA, plasminogen activators; PMA, phorbol myristate acetate; RGC, radial glial cell; Shh, sonic hedgehog; TGF $\beta$, transforming growth factor beta; TNF $\alpha$, tumor necrosis factor alpha; uPAR, urokinase palsminogen activator receptor; VEGF, vascular endothelial growth factor.
}

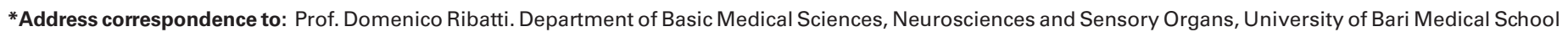
Policlinico - Piazza G. Cesare, 11, 70124 Bari, Italy. Tel: + 39.080.5478326. Fax: + 39.080.5478310. E-mail: domenico.ribatti@uniba.it (iD) https://orcid.org/0000-0003-4768-8431
}

Submitted: 29 January, 2020; Accepted: 12 May, 2020.

ISSN: Online 1696-3547, Print 0214-6282

(C) 2020 UPV/EHU Press

Printed in Spain 
in culture, while when recombined with their mesenchyme, these explants resume to their normal morphogenesis. However, mesenchyme-free culture has been established in 1995 (Nogawa and Ito, 1995) and extensively used as a model system. The emergence of branches in cultures of mesenchyme-free lung epithelium has been indicated as the result of diffusion-limited growth (Hartmann and Miura, 2006).

Epithelial growth and branching can be stimulated by heterologous mesenchyme: salivary mesenchyme support thymic (Auerbach, 1960), pancreatic (Golosow and Grobstein, 1962), and mammary (Kratochwil, 1969) branching in culture. Moreover, grafts of mesenchyme from various organs promoted the formation of an ectopic bud when sections of tracheal mesenchyme were dissected away, but only lung mesenchyme was able to induce subsequent branching morphogenesis (Spooner and Wessells, 1970, Wessells, 1970).

ECM plays an instructive role in branching morphogenesis (Williams and Daniel, 1983). Fibrils of interstitial collagen (Fukuda et al., 1988, Nakanishi et al., 1988) and fibronectin (Sakai et al., 2003) accumulate at sites od cleft initiation. Exogenous fibronectin in the culture medium induces clef formation in the salivary explants. Fibronectin is also required for branching morphogenesis of the lung and kidney (Roman, 1997, Sakai et al., 2003). The epithelium increases its expression of $\alpha 6, \beta 1$, and $\beta 4$ integrin during the branching process in response to epidermal growth factor (EGF) (Kashimata and Gresik, 1997). The mammary gland epithelium interacts with the surrounding ECM primarily through $\beta 1$ integrin and silencing of $\beta 1$ integrin prevents branching morphogenesis (Mori et al., 2012), matrix metalloproteinase 14 (MMP14) is expressed at high levels by epithelial cells within the terminal buds of the pubertal mouse mammary glands and by cells at branch sites in culture (Mori et al., 2009, Mori et al., 2012).

Processes of branching morphogenesis, however, are not limited to multicellular organs, but also shape single cell types. The typical example are neurons (Gibson and Ma, 2011, Kalil and Dent, 2013), that develop and extend multiple branches forming terminal arbors allowing these cells to integrate information from divergent regions of the nervous system. In this case, branching morphogenesis is a process inducing a rearrangement of the cytoskeleton in response to extracellular cues and neuronal activity.

In the first part of the present review, the main biological aspects of branching morphogenesis in five systems (kidney, lung and mammary gland as examples of multicellular tree topology which is primarily generated by collective migration of epithelial sheet, vascular system as an example of multicellular/network topology, and neurons, as an example of unicellular topology) will be briefly recapitulated.

These systems differ in many aspects, that include the topology of the pattern they exhibit (vessels, for instance, generate a network of interconnected structures instead of a branching tree), the number of cells involved (neurons are single cells) and the morphogens driving the developmental process.

In recent years, however, based on quantitative analyses of large-scale structure reconstructions and kinetics measurements it has been suggested that branching morphogenesis could be explained within a single unifying framework as a self-organized process reliant on a set of simple local rules (Hannezo et al., 2017, Lang et al., 2018). This perspective will be also briefly discussed.

\section{Kidney}

The development of the kidney starts when the ureteric bud, a local evagination of the Wolffian nephric duct, grows into metanephrogenic mesenchyme. The epithelium of the ureter forms a network of tubules that are embedded in the mesenchyme, part of which differentiates into epithelia which organizes themselves into proximal tubes (nephron segments) and which join the distal tubules of the arborizing ureter, while the remainder provides the cellular matrix in which these tubules are embedded (Saxen, 1987). The invasion of the surrounding mesenchyme occurs through a process of dichotomous ductal branching (Fig. 1) (Watanabe and Costantini, 2004)

Reciprocal inductive interactions occur between the epithelium of the ureter and the adjacent mesenchyme (Grobstein, 1955, Saxén, 1970). Grobstein $(1955,1956)$ cultured in vitro the ureteric epithelium and the adjacent mesenchyme alone or together, and demonstrated that the ureteric epithelium did not branch in the absence of the mesenchyme, while when they were cultured together, the epithelium branched and the nephrons formed regularly. The incipient epithelium induced the expression of tenascin in the adjacent mesenchyme (Aufderheide, 1987). The signal from the mesenchyme is glial-derived neurotrophic factor (GDNF) while

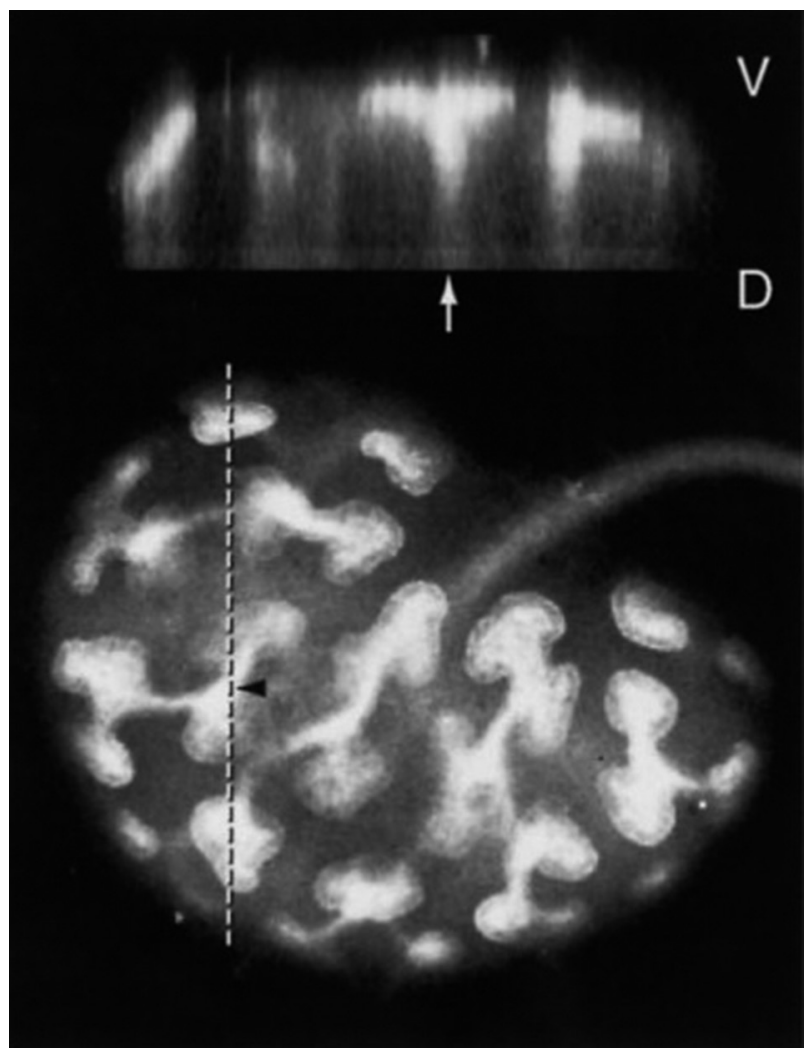

Fig. 1.Three-dimensional branching of the ureteric bud. Confocal images of an E15 kidney with ureteric buds stained with anti-cytokeratin antibodies. The $X-Y$ plane (lower panel) was sectioned at the dotted line to generate the $Y$-Z plane shown in the upper panel. In the top panel the white arrow shows a dividing branch in the $Y Z$, that is, dorso-ventral plane. Its location in the $X-Y$ plane below is marked by a black arrowhead. (Reproduced from al-Awqati and Goldberg, 1998). 


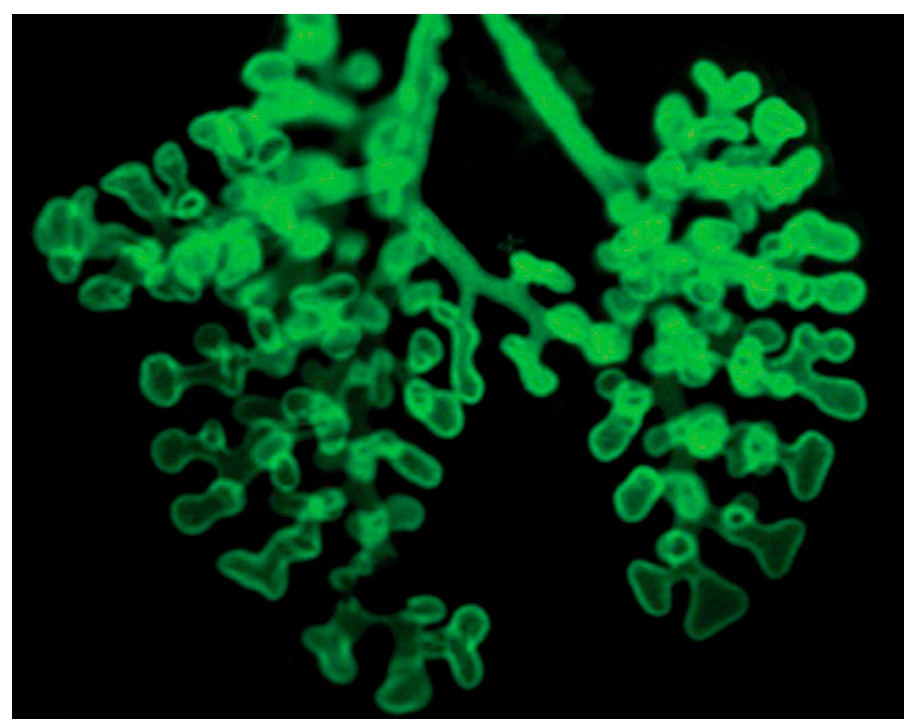

Fig. 2. Branching morphogenesis in the mouse lung. Immunofluorescent staining of $E$ cadherin in the branching epithelium of whole-mount lung (Modified from Lu and Werb, 2008).

its receptor RET is expressed in the ureteric bud (Shakya et al., 2005) Mice with either the GDNF or RET gene knocked out form no kidney. If a GDNF slow-release bead is placed on a culture of nephrogenic mesenchyme from these embryos, then branching of the duct is restored in the GDNF knock out, which lacks the factor, but not in the RET knockout, which lacks the capacity to respond to it.

Only the metanephrogenic mesenchyme is able to respond to the ureteric bud and form kidney tubules; if induced by embryonic salivary gland or neural tube tissue, metanephrogenic mesenchyme responds by forming kidney tubules and no other structures (Sariola et al., 1982, Saxen, 1987).

Madin-Darby canine kidney (MDCK) cells generate tubule-like structures in vivo, and grown within three-dimensional collagen gels, form spherical cysts (McAteer et al., 1987). MDCK cells suspended within a collagen gel contiguous to a fibroblast-populated gel layer form branching tubules instead of the spherical cysts that develop in the absence of fibroblasts; MDCK cells grown as a monolayer on a cell-free collagen gel cast layer invade the underlying collagen matrix, forming a network of branching tubules; fibroblast-conditioned medium mimics the effect of coculture by eliciting tubule formation by MDCK cells (Montesano et al., 1991b). Moreover, MDCK cells grown in collagen gels in the presence of the hepatocyte growth factor (HGF) formed linear or branching tubular structures; MDCK cells grown in the presence of fibroblast-conditioned medium pre-incubated with specific anti-HGF antibodies exclusively formed spherical cysts similar to those observed in the absence of conditioned medium; anti-HGF antibodies suppressed tubulogenesis in co-cultures of MDCK cells and fibroblasts (Montesano et al., 1991a).These data demonstrated that the fibroblast-derived factor that induces tubule formation by MDCK cells is HGF. When MDCK cells were grown in fibrin gels instead of collagen gels, HGF-induced tubule formation was prevented by the addition of serine proteinase inhibitors (Montesano et al., 1991b); conditioned medium from fibroblasts increased uPA activity and mRNA by about 5 -fold and this effect was completely inhibited by pre-incubation of conditioned medium with anti-HGF antibodies; exogenously added recombinant HGF induced a comparable increase in uPA activity and mRNA in MDCK cells; both fibroblast-conditioned medium and HGF induced a more than 30-fold increase in UPAR mRNA in MDCK cells (Pepper et al., 1992b). These data suggest that epithelial tubulogenesis is dependent on extracellular plasmin-dependent proteolysis, which results from a concomitant increase in UPA and uPAR expression.

\section{Lung}

The experiments of Rudnick (Rudnick, 1933) with grafts of chick lung strongly suggested that budding of the bronchial tree does not take place when the epithelium is deprived of its investing mesenchyme and she concluded that factors necessary for the production of orderly branching of the endodermal bud lie within the surrounding mesenchyme. Loffredo Sampaolo and Sampaolo (Loffredo Sampaolo and Sampaolo, 1961) cultivating chick and rabbit lung on a defined medium, discovered that removal of the mesenchyme from the right lung interrupts the process of epithelial branching. The unaltered left lung, adjoining, continues to branch normally. Dameron (1961) demonstrated that the epithelium of fetal lung, isolated in vitro, is incapable of morphogenesis. When the epithelium is recombined with pulmonary mesenchyme, development resumes. Using short-term cultures of cells dissociated from embryonic lung, Grover (Grover, 1961a) found that when the medium is seeded, the cells begin to re-aggregate into one mass. Moreover, the effectiveness of both dissociation and re-aggregation decreased with increasing age (Grover, 1961b). Mesenchyme, separated from fetal mouse lung and placed on plasma clots at some distances from the bare tracheobronchial tree, will migrate toward the epithelium and arrange itself about the epithelium. Following re-association, epithelial branching proceeds and this process is maximally inhibited after irradiation of both components (Alescio et al., 1963). Alescio and Cassini (Alescio and Cassini, 1962a, Alescio and Cassini, 1962b) demonstrated that if a section of mesenchyme from the tracheal bud is removed and replaced by mesenchyme taken from a bronchial bud, and if the grafted lungs is cultivated in vitro, a supernumerary bud grows out from the epithelium beneath the grafting site. Normally, the trachea produces no extra branches.

The respiratory epithelium of an embryonic mouse can be isolated soon after it has split into two bronchi, and the entire rudiment can be cultured. When the right bronchial epithelium was allowed to retain its lung mesenchyme, it proliferated and branched under the influence of the lung mesenchyme (Fig. 2). Otherwise, the left bronchus surrounded with tracheal mesenchyme, continued to grow in an unbranched manner (Wessells, 1970).

The epithelial lung buds can be induced to form also gastric glands, villi epithelia or hepatic cords, in the presence of the corresponding mesenchyme (Deuchar, 1975). The composition of the extracellular glycosaminoglycans (GAGs) varies during different phases of lung development and influence branching and differentiation of lung epithelium (Becchetti et al., 1988, Shannon, 1994). The branching morphogenesis of the developing lungs involves a lateral inhibition-type system whereby new tips produce fibroblast growth factor-10 (FGF-10) and suppress the formation of other tips in their immediate neighborhood.

The Drosophila tracheal system has three generations of 


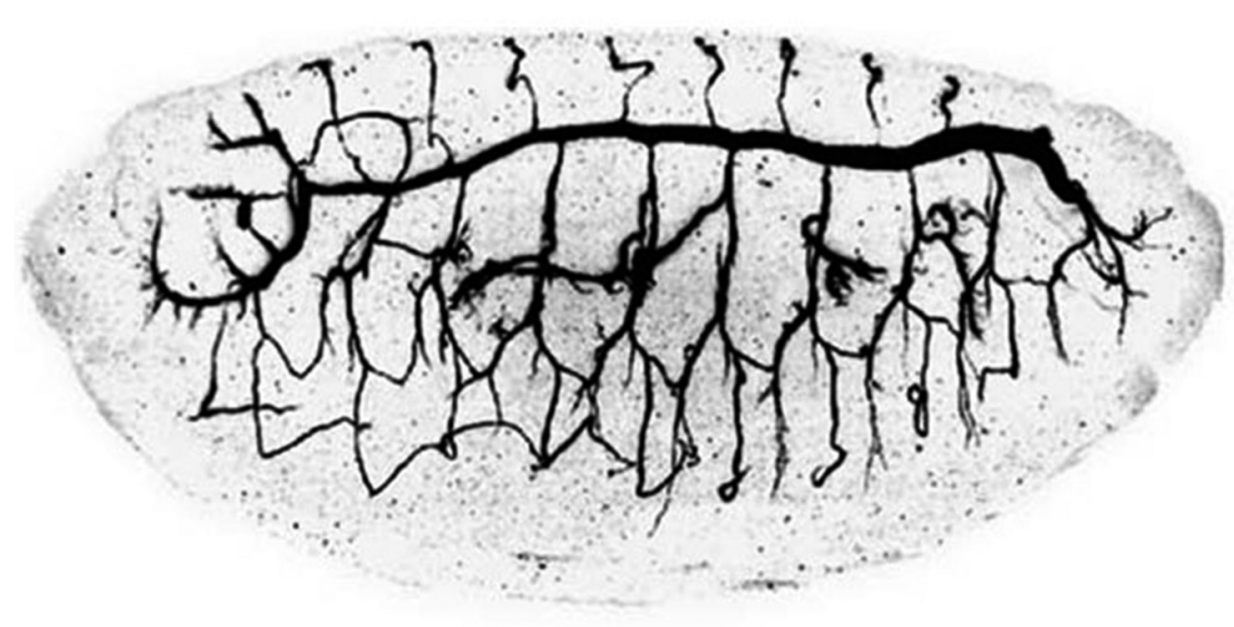

Fig. 3.The tracheal system in Drosophila larvae. It is a relatively simple model system for the study of branched structures and has provided some amazing insights into the biology of branching morphology. levels of c-met mRNA in mammary cells, thus providing a possible mechanism for c-met downregulation in the rat mammary gland during lactation.

Low concentrations of TGF- $\beta 1$ promote the elongation and branching of mammary cells, whereas high levels have inhibitory effects (Soriano et al., 1996)Mammary epithelial cells grown in collagen gels in chemically defined medium form spherical cysts. The addition of acidified foetal calf serum (FCS) to the defined medium induced the formation of branching tubes (Montesano, 2007). The use of a pharmacological inhibitor of TGF- $\beta$ receptor signalling and a neutralizing antibody to TGF- $\beta 1$, identified the active component in acidified FCS as TGF- $\beta 1$. Moreover, the effect of acidified FCS was replicated by the addition of exogenous TGF- $\beta 1$. Overall, branches: primary, secondary and terminal (Fig. 3) (Ghabrial et al., 2003). The expression of the FGF homolog Branchless (Bnl) specifies the tip cell which inhibit tip cell phenotype in the neighboring stalk cells through Delta-Notch signaling (Ghabrial and Krasnow, 2006, Sutherland et al., 1996). Initially, the lumen of the primary branch is surrounded by multiple stalk cells. Then, they rearrange to generate an epithelium in which the lumen is surrounded by a single cell. In the mouse lung, during the early stages of development, lateral branching is prevalent, later planar bifurcation, and finally orthogonal bifurcation (Metzger et al., 2008)

FGF-10 drives outgrowth of limb buds (Bellusci et al., 1997). High expression levels of FGF10 are observed on the distal mesenchyme of the tip, as well as on the sides of the tips of a bud. The concentration of FGF10 at the distal tip of the limb bud directs elongation, whereas terminal branching is the result of a split localization of FGF10, and lateral branching is the result from FGF10 signaling restricted to spots on the side.

\section{Mammary gland}

Fibroblast-conditioned medium stimulated the development of an extensive system of highly arborized duct-like structures in mammary cells (Fig. 4) (Soriano etal., 1995) Moreover, the effect of fibroblastconditioned medium was completely abrogated by antibodies to HGF, whereas the addition of exogenous HGF to the cultures mimicked the tubulogenic activity of conditioned medium. Finally, the effect of HGF was markedly boosted by the simultaneous addition of hydrocortisone, which also enhanced lumen formation (Soriano et al., 1995).

The levels of both HGF and its receptor c-met mRNA progressively reduced during pregnancy, were undetectable during lactation, but increased during the involution phase up to pre-pregnancy levels (Pepper et al., 1995). Moreover, after 3 days of lactation both HGF and c-met transcripts were once again reduced to undetectable levels in the mothers. Finally, prolactin significantly reduced the these findings demonstrate that, at low concentrations, TGF- $\beta 1$ can activate a morphogenetic program resulting in the formation of epithelial tubes. A dose-dependent increase in MMP-9 was observed following TGF- $\beta 1$ treatment, and tube formation was suppressed by a synthetic broad-spectrum MMP inhibitor, by a recombinant tissue inhibitor of MMP-2 and by a selective inhibitor of MMP-9, indicating that this morphogenetic process requires the activity of MMP-9 (Montesano et al., 2007).

Retinoic acid induces the formation of lumen-containing colonies (cysts) in cultured mammary epithelial cells (Montesano and Soulie, 2002). Moreover, a dose-dependent increase in the latent and active forms of MMP-9 following retinoic acid treatment, was observed, and lumen formation was abrogated by the addition of the synthetic MMP inhibitor, indicating that this morphogenetic process likely requires MMP activity. Tumor necrosis factor alpha (TNF- $\alpha$ ) causes multicellular colonies of mammary epithelial cells to disaggregate and induces cells grown on top of a collagen gel to invade the underlying matrix (Montesano, 2005). TNF- $\alpha$ confers to mammary epithelial cells several additional properties that are char-

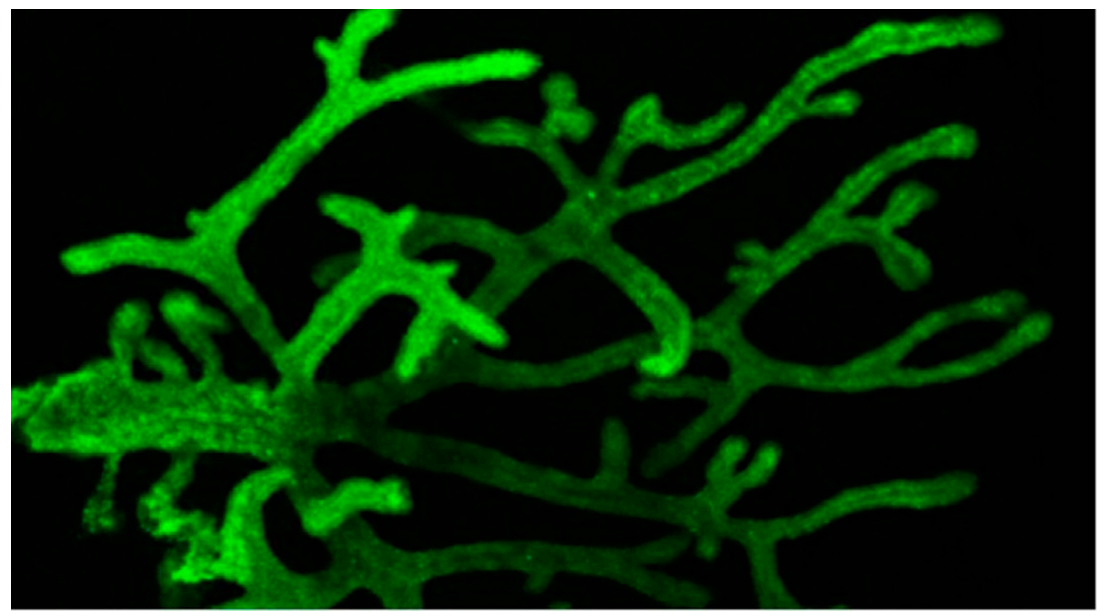

Fig. 4. Branching morphogenesis in the mammary gland of a 4 day-old mouse. (Credit: Olivia Harris, Felicity Davis, Bethan Lloyd-Lewis and Christine Watson, University of Cambridge, Wellcome Images). 
acteristics of malignantly transformed cells, including proliferation in the absence of exogenously added growth factors, anchorageindependent growth and the loss of contact-mediated inhibition of proliferation (Montesano, 2005). Bone morphogenetic protein 4 (BMP4) disrupts cyst organization in a concentration-dependent manner, causing lumen obliteration, the extension of invading cell cords, and three-dimensional cell scattering (Montesano, 2007).

\section{Vascular system}

Tree structure in vasculature is established by remodeling by flow and fundamentally different from kidney, lung and mammary gland. Branching is but one of the processes that form the vascular system (Fig. 5), including cell proliferation, guided migration, tubulogenesis, vessel fusion, and vessel pruning. Branching involves the sprouting of new vessels. The term angiogenesis, applied to the formation of capillaries from pre-existing vessels, i.e. capillaries and post-capillary venules, is based on endothelial sprouting or intussusceptive (non-sprouting) microvascular growth (Burri and Tarek, 1990, Risau, 1997). During angiogenesis, microvascular endothelial cells focally degrade their investing basement membrane, and subsequently migrate into the interstitial matrix of the surrounding connective tissue (Ausprunk and Folkman, 1977). The sprout elongates by further migration and by endothelial cell proliferation proximal to the migrating front, and a lumen is gradually formed proximally to the region of proliferation. Contiguous tubular sprouts anastomose to form functional capillary loops, and vessel maturation is accomplished by means of reconstitution of the basement membrane (Ausprunk and Folkman, 1977).

When a monolayer of microvascular endothelial cells on the surface of a collagen gel is covered with a second layer of collagen, it reorganizes within a few days into a network of branching and anastomosing tubules, without invading the underlying matrix, demonstrating that a three-dimensional interaction with collagen fibrils plays an important role in driving capillary morphogenesis (Montesano, 1983). Furthermore, when confluent monolayers of microvascular endothelial cells on collagen gels were treated with phorbol myristate acetate (PMA), a tumor promoter that markedly stimulated the production of collagenase and plasminogen activators (PAs), whereas control endothelial cells were confined to the surface of the gels, PMA-treated endothelial cells invaded the underlying collagen matrix, where they formed capillary-like tubular structures (Montesano and Orci, 1985).

Basic fibroblast growth factor (bFGF) and vascular endothelial growth factor (VEGF) induced the endothelial cells to invade the underlying collagen matrix and to form capillary-like tubules, and stimulated the endothelial cells to produce PAs (Montesano et al., 1986, Pepper et al., 1992a) Moreover, when added simultaneously, VEGF and bFGF induced an in vitro angiogenic response which was greater than the sum of the two, and which occurred with greater rapidity than the response to either cytokine alone (Pepper et al., 1992a). TGF- $\beta 1$ at low concentrations decreased bFGF- or VEGF-induced invasion, whereas at high concentrations it increased invasion (Pepper et al., 1992b).

Other evidence demonstrating an increased uPA and urokinase plasminogen activator receptor (UPAR) expression in endothelial cells migrating from the edge of an experimental wound in vitro (Pepper et al., 1992a, Pepper et al., 1987), supported the role of the PA/plasmin system in angiogenesis.

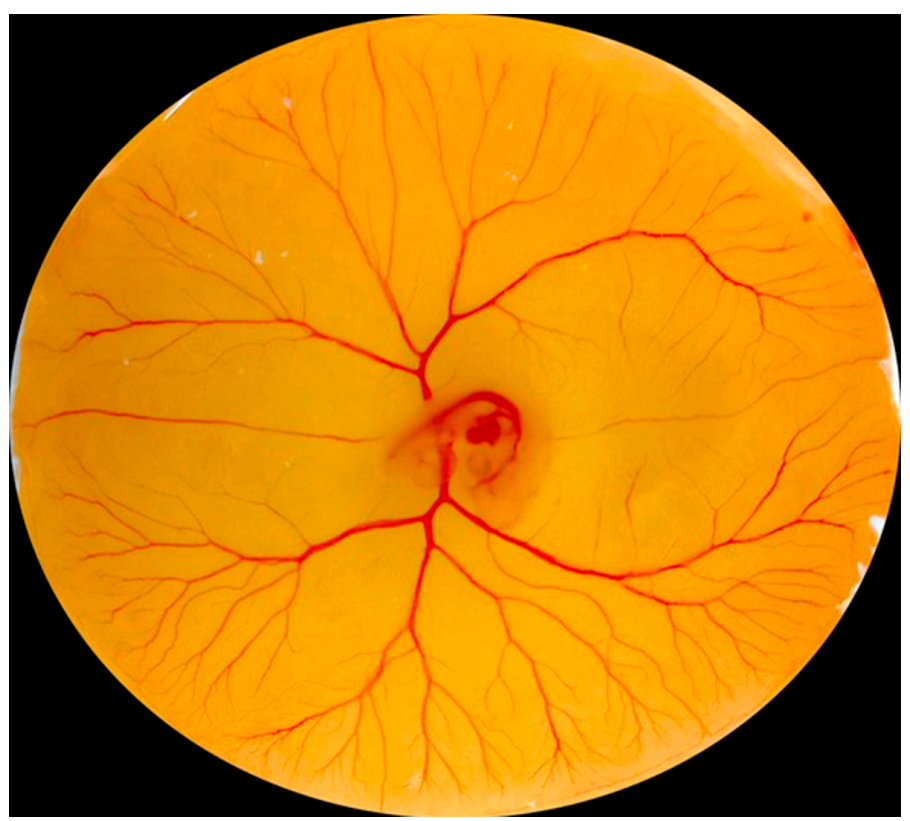

Fig. 5. Vascular branching in the chick embryo yolk sac.

In the Vertebrate vasculature, tip cells are selected by VEGF-A which induces signalling down-stream of VEGFR-2 to up-regulate the expression of Delta-like4 (DII4) (Hellström et al., 2007, NogueraTroise et al., 2006, Suchting et al., 2007). Cells with the highest levels of DIl4 become tip cells and lead to the growing branch (Jakobsson et al., 2010). Activation of Notch signalling in the adjacent cells reduces their expression of VEGFR-2 inducing them to become stalk cells (Kume, 2009). The final topology of the vasculature is different compared to other branched structures, because it is not a blind-ending tree, but rather consists of arterial and venous tree that are interconnected via a capillary bed.

Embryonic vessel formation is also highly dynamic and subject to intense pruning and remodeling throughout development. Local alterations in perfusion produce dramatic changes in vascular patterning throughout the embryo (le Noble, 2003), and in adult vessels, vessel segments can adapt to the amount of flow carried (Peirce and Skalak, 2003).

Intussusceptive branching remodeling leads to modification of the branching geometry of supplying vessels, optimizing pre- and post-capillary flow properties and lead to the removal of branches by pruning in response to changes in metabolic needs. Intussusceptive branching remodeling do not requires the proliferation of endothelial cell, rather the rearrangement and remodeling of existing ones (Djonov et al., 2003).

\section{Neurons}

Neurons form branched structure but is single cell level phenomenon with completely different mechanism. During development, neural stem cells (NSCs) are the source of all neurons as well as of the two types of macroglial cells in the central nervous system (CNS) (astrocytes and oligodendrocytes) and of the ependymal cells (Guidolin et al., 2018). Neuroepithelial cells represent the basic form of NSC, the germinal cells from which directly or indirectly all nerve cells derive. They form the primitive wall of the neural tube 
lining the lumen. Like all the epithelial cells, neuroepithelial cells are highly polarized, with an apical pole oriented inward to contact the lumen surface and a basal pole oriented outward towards the pial surface of the neural tube (Medelnik et al., 2018). In humans, at approximately gestation week 5-6, the neuroepithelial cells downregulate some epithelial features such as tight junctions (Aaku-Saraste et al., 1996). At the same time, they take on glial characteristics including intermediate filament proteins such as glial fibrillary acidic protein (GFAP), glycogen storage granules, the $\mathrm{Ca}^{2+}$ binding protein $\mathrm{S} 100 \beta$ and the astrocyte-specific glutamate transporter GLAST (Campbell and Götz, 2002). These changes mark the transition of neuroepithelial cells to radial glial cells (RGCs). The conversion requires the activation of the Notch-signaling pathway (Hatakeyama, 2004), which is also a key factor for the maintenance of the cell identity and self-renewal (Rubenstein and Rakic, 2013). RGC will then undergo many asymmetric divisions generating daughter RGC and differentiated neurons or more restricted progenitors (Gotz and Huttner, 2005). Through consecutive waves of neurogenesis, nascent neurons migrate radially along the RGC process into the most superficial layer of the developing tissue where they mature. These steps occur through the action of morphogens (Grove and Monuki, 2013), including sonic hedgehog (Shh), retinoic acid, bone morphogenetic proteins (BMPs), and FGF.

In vivo, most neurons undergo axon-dendrite polarization during migration (Polleux, 2013) and a careful examination of the process revealed that neurons can inherit their axon and dendrite polarity from the apico-basal polarity of their progenitors (Barnes and Polleux, 2009). Neocortical pyramidal neurons, for instance, form a leading process and a trailing process while migrating, each becoming the axon or the dendrite. Evidence suggests that the events leading to the emergence of the axon and the dendrites require the ability of post mitotic neurons to sense gradients of extracellular cues, such as TGF $\beta$ (Yi et al., 2010) and BDNF (Shelly et al., 2007). As neurons complete their migration, they extend axons and dendrites to appropriate synaptic partners. The complex regulation of axon branching can be broken down into several developmental steps, which include branch formation, growth, guidance and pruning, as well as branch interactions, such as competition, self-avoidance and tiling (Gibson and Ma, 2011, Kalil and Dent, 2013). The phenotype attained by a neuron is firstly determined by extracellular cues and experimental evidence suggests that many of the cues known to serve early developmental steps of neurite outgrowth may also modulate the more advanced stages of neural arborization (Acebes and Ferrús, 2000, Bilimoria and Bonni, 2011, Kollins and Davenport, 2005). They include extracellular matrix factors and adhesion molecules, neuronotrophic factors, hormones and hormone-like factors, chemoattractant and chemorepellent molecules, as, for instance, chemokines (Deverman and Patterson, 2009). However, the wide diversity in neural cytoarchitecture also suggests that each neuronal population is predisposed to develop particular arbor characteristics through cell type specific constraints on branching (Flynn et al., 2013, Kollins and Davenport, 2005). Neuronal branching morphogenesis, for instance, depends on structural features, such as the size of the perikaryon, intrinsically delimiting the number and area of primary axons and dendrites and associated branch projections (Hillman, 1988, Mitchison, 1991). Furthermore, neurite branching is limited by the biophysical features of cytoskeletal structures and in particular by the minimum number of microtubules required to maintain structural stability (Baas, 1997). An additional form of intrinsic control over neuronal morphology is produced through the expression of genes independent from extracellular cues, such as kinases and their regulators (Diaz-Hernandez et al., 2008, Drinjakovic et al., 2010, Jones et al., 2003), transcription factors (Dasen, 2009, Livet et al., 2002) and the Rho family small GTPases, involved in cytoskeleton regulation (Hall and Lalli, 2010).

Axon branching usually occurs as a dynamic process that involves branch addition and branch retraction (Fig. 6). As shown

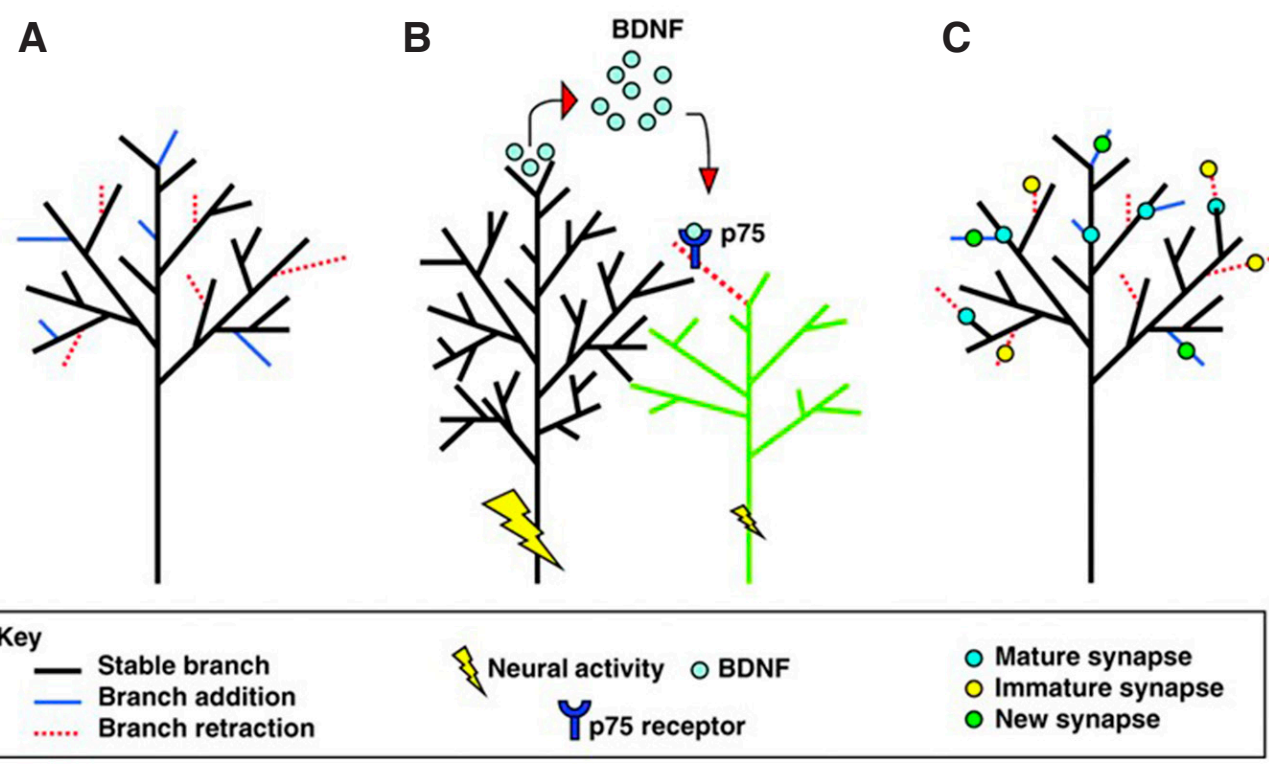

Fig. 6. Mechanisms underlying activity-dependent regulation of axon branching. (A) Axon branching often occurs as a dynamic process that involves branch addition and branch retraction. Branching dynamics can be modulated by neural activity to produce a bias toward branch addition or retraction, leading to a net change in the arbor morphology. (B) Neighboring axonal branches compete for innervation territoryin the target structure. Typically, the axon experiencing the greatestamount of activity 'wins' the competition by inhibiting the arborization of neighboring axons. In sympathetic neurons, this phenomenon might be mediated by a brain-derived neurotrophic factor (BDNF)-nerve growth factor receptor (p75) interaction, in which the 'winning' branch secretes BDNF that then binds to the 75 receptor on the 'losing' axon, resulting in the loss of that branch due to axon degeneration (illustrated here as branch retraction for simplicity). (C) Axon branching is tightly coupled to synapse development. The maturity of new synapses is a significant criterion for determining which branches will be retained or retracted, in addition to where new branches will form. Mature synapses can halt branch retraction, whereas immature synapses are associated with retracting branches. New synapses preferentially form on new branches, and new branches preferentially form near mature synapses. (Reproduced from Gibson and Ma, 2011). 
by quite recent studies, branching dynamics can be modulated by neural activity to produce a bias toward branch addition or retraction, leading to a net change in the arbor morphology (Gibson and $\mathrm{Ma}, 2011$ ). This activity-dependent axon branching is driven by a variety of constraints, including wiring optimization (Bird and Cuntz, 2016) and energy consumption (Ju et al., 2016). The influence of neuronal structure on activity patterns has also been explored by several studies. The effects of complex axonal geometries on spike trains were described in simulation studies (Bove et al., 1994, Manor et al., 1991, Ofer et al., 2017) and the influence of the axonal morphology on activity was also demonstrated in experimental investigations (Sasaki et al., 2011, Sasaki et al., 2012, Stockbridge, 1988, Stockbridge and Stockbridge, 1988). Recently, a quite detailed analysis focused on the two basic units of the neuronal branching trees, i.e. axonal linear segments and axonal branching points, has been proposed (Ofer et al., 2017). It illustrated how asymmetric responses can emerge in axonal branching points, suggesting that axonal morphological parameters could be instrumental to information coding. These findings, therefore, open the possibility that in addition to the abovementioned wiring optimization and energy consumption, information coding considerations may also drive neuronal structure.

\section{Can a unified theory of branching morphogenesis be identified?}

In the previous sections the main developmental steps of five systems exhibiting a branching pattern have been briefly discussed. From the cell biology standpoint, they differ in many respects. The mammary gland branching morphology is characterized by a 2D geometry, while kidney, lung, vessels and neurons develop as 3D system of branches. Unlike mammary gland, lung and kidney, however, vessels self-organize in a network of interconnected tubular structures. Furthermore, while mammary gland, lung, kidney, and vessels are multicellular pattern formation, primarily generated by collective cell migration, neurons are single cells where branching involves the rearrangement of cytoskeletal elements (actin fibers and microtubules) and of the cell membrane. At the molecular scale, regulatory signaling pathways play a key role in controlling the process of branching in the different organs (Iber and Menshykau, 2013), but, as discussed in the previous sections, the morphogens involved are not always the same. In lung and kidney, for instance, FGF10 and GDNF signaling is essential to guide directional bud outgrowth, to sustain progenitor cells fate and to affect gene expression (Bellusci et al., 1997, El Agha et al., 2013, Zhao et al., 2004), while the interplay of VEGF and Notch signaling drives the development of the vascular network (Hellström et al., 2007, Kume, 2009, Noguera-Troise et al., 2006, Suchting et al., 2007), and neurotrophic factors, guidance cues and morphogens represent significant regulatory factors of neuron morphology (Kalil and Dent, 2013). Because of such a microscopical complexity, although relevant transcription factors and signaling networks have been intensively studied, it remains quite unclear how morphological patterns emerge from their interplay (Lang et al., 2018). Mathematical modeling has proven to be a valuable approach to address this point (Macias and Hinck, 2012) and, as a consequence, a wide range of modelling approaches have been established (see (Lang et al., 2018) for recent reviews). They differ in terms of the mathematical framework applied to model branch- ing morphogenesis (as a deterministic stereotypic program or as a stochastic process) and in terms of spatial scale considered (e.g. cell or tissue level), sometimes offering contrasting perspectives (Hannezo et al., 2017).

In this respect, it can be of interest to observe that, when the large-scale morphology is considered, all the biological systems here analyzed share common features. In particular, they exhibit structural patterns characterized by a high degree of self-similarity, that can be well described by using concepts from fractal geometry (Guidolin et al., 2011, Guidolin et al., 2016, lonescu et al., 2009, Nelson et al., 1990), and in some of these systems fractal geometry has also been proven as a useful tool to devise morphometric methods suitable to quantitatively evaluate their structural features (Guidolin et al., 2004, Porzionato et al., 2016). Thus, very recently it has been suggested by some authors that a unified framework to explain branching morphogenesis could be identified by considering the large-scale structural organization of the complex networks emerging from this developmental process without largely addressing the detailed underlying molecular and cellular regulatory processes (Hannezo et al., 2017, Hannezo and Simons, 2018, Lang et al., 2018). According to a terminology used in physics, such a view can be considered as a "phenomenological approach", since it aims at understanding the action of a morphogenetic program without resolving its microscopical basis, but may provide the means to frame specific questions into a more microscopic level of description (Hannezo and Simons, 2018).

In this context, Lang and collaborators (Lang et al., 2018) suggested the ligand-receptor based Turing mechanism as a potential candidate for a general regulatory mechanism for branching morphogenesis. The Turing mechanism, originally proposed by Turing (Turing, 1952), is based on the availability of at least two regulatory factors with substantially different diffusion rates that interact in a cooperative way leading to the upregulation of one of the factors. These requirements are typically fulfilled by many ligand-receptor systems (including those here discussed) and lead to the self-organized emergence of many different kind of patterns. As a matter of fact, this strategy has been explored in models of lung branching morphogenesis including FGF10 and sonic hedgehog $(\mathrm{SHH})$ as key signaling factors (Celliere et al., 2012) and has been applied to kidney branching morphogenesis by considering the regulatory interaction between GDNF and WNT11 (Menshykau and Iber, 2013). A model of branching morphogenesis based on the so-called theory of "branching and annihilating random walks" (BARWs), a class of models extensively studied by physicists (Cardy and Täuber, 1996), has been proposed by (Hannezo et al., 2017) as a possible unifying theory of branching morphogenesis. It is based on a simple set of local statistical rules, including stochastic tip branching, random exploration of space and branch elongation and tip termination in high density regions. The model was applied to the morphogenesis of the mammary gland epithelium with good accuracy and then extended to the analysis of kidney development (Shannon, 1994). BARW was also used to model the branch dynamics governing shape characteristics of cerebellar Purkinje cell dendrites (Fujishima et al., 2012). It is worth noting that BARW phenomenology with its branching and annihilating dynamics can emerge naturally from Turing-type models (Meinhardt, 1982), see also (Howaed and Tauber, 1997) for a mathematical discussion of the topic), indicating a substantial convergence of the two strategies and suggesting that branching morphogenesis 
of complex tissues can be understood and predicted on the basis of simple sets of local rules.

The reported results, obtained following the abovementioned approaches, appear indeed quite accurate in reproducing the outgrowth and the physiological geometries of systems characterized by branching morphogenesis. The emerging patterns, however, are typically dependent on the initial conditions and on the choice of simulation parameters, indicating that within the just mentioned general theoretical frameworks initial conditions and setup parameters likely reflect important specific features of each specific system. In this respect, for instance, studies exist showing that mechanical stresses (associated with interactions with the extracellular matrix) significantly influence branching morphogenesis (Lang et al., 2018). Likewise, developing neurons experience pattern of activity that contribute to the initial development and subsequent refinement of their morphology (Gibson and $\mathrm{Ma}, 2011)$. Thus, to increase their efficiency, modeling approaches should also account these aspects (Tanaka, 2015).

\section{Theoretical studies on branching morphogenesis}

Extensive investigations have identified features shared by all branched organs, which are formed by repeated cycles of branching together with phases of ductal elongation (Iber and Menshykau, 2013). Overlapping explanations based on mechanical (Gjorevski and Nelson, 2011) or viscous (Lubkin and Murray, 1995) models have been proposed, and processes such as oriented cell divisions (Yu et al., 2008), collective cell migration (Huebner et al., 2016, Riccio et al., 2016), and cytoskeleton-driven cell shape changes (Elliott et al., 2015, Kim et al., 2015) have been shown to play a role. A receptor-ligand based Turing model for the control of branching morphogenesis has been proposed in both lung and kidney, as well as other patterning processes in various developmental systems (Iber and Menshykau, 2013). Hannezo et al., (Hannezo et al., 2017)have investigated how the branching pattern of the mouse mammary gland epithelium and kidney emerge throughout development. Using a combination of whole-organ 3D reconstruction, proliferation kinetics, and biophysical modeling, they have demonstrated that branching morphogenesis proceeds from the spatial competition of equipotent tips, which randomly explore space through a process of ductal elongation and stochastic branching.

\section{Concluding remarks}

The development of organs involves similar processes. Epithelia are the commonest type of tissue organization found in animals and play a key role in the development of many organs (Arechaga et al., 1983). It is common for epithelia involved in organogenesis to branch and for tubules and to be induced by the adjacent mesenchyme. Advanced imaging techniques and genetic manipulations provide powerful tools to address fundamental questions of branching morphogenesis and patterning.

Although numerous identified transcripts, genes, and molecular pathways are responsible for the epithelial spatial organization of the organs, the way in which epithelial cells move and rearrange to form tissues is incompletely understood. The early branching events are different between organs, by are highly stereotyped, as occurs in kidney and lung, and must therefore be carefully controlled.
Improving our understanding of how cells move during regulated epithelial morphogenesis is not only of interest to developmental biology for the purpose of filling gaps in knowledge, but it can contribute to an enhanced understanding of the pathologically dysregulated cell movements during the early stages of cancer metastasis progression.

\section{References}

AAKU-SARASTE, E., HELLWIG, A. and HUTTNER, W.B. (1996). Loss of Occludin and Functional Tight Junctions, but Not ZO-1, during Neural Tube Closure-Remodeling of the Neuroepithelium Prior to Neurogenesis. Dev. Biol. 180: 664-679.

ACEBES, A. and FERRÚS, A. (2000). Cellular and molecular features of axon collaterals and dendrites. Trends Neurosci. 23: 557-565.

AFFOLTER, M., BELLUSCI, S., ITOH, N., SHILO, B., THIERY, J.-P. and WERB, Z (2003). Tube or Not Tube. Dev. Cell 4: 11-18

AL-AWQATI, Q. and GOLDBERG, M.R. (1998). Architectural patterns in branching morphogenesis in the kidney. Kidney Int 54: 1832-42.

ALESCIO, T. and CASSINI, A. (1962a). Inductionin vitro of tracheal buds by pulmonary mesenchyme grafted on tracheal epithelium. J. Exp. Zool. 150: 83-94.

ALESCIO, T. and CASSINI, A. (1962b). L'interazione epitelio-mesenchimale nell'organogenesi del polmone embrionale di topo coltivato in vitro. Zeitschrift für Anatomie und Entwicklungsgeschichte 123: 369-396.

ALESCIO, T., CASSINI, A. and LADU, M. (1963). Ricerche sulla riassociazione in vitro dell'epitelio e del mesenchima del polmone embrionale di topo, dopo dissociazione triptica ed irradiazione con raggi gamma. Arch Ital Anat Embriol 68: 1-44.

ARECHAGA, J., KARCHER-DJURICIC, V., RUCH, J.V. (1983). Neutral morphogenetic activity of epithelium in heterologous tissue recombinant. Differentiation 25: $142-147$.

AUERBACH, R. (1960). Morphogenetic interactions in the development of the mouse thymus gland. Dev. Biol. 2: 271-284.

AUFDERHEIDE, E. (1987). Epithelial-mesenchymal interactions in the developing kidney lead to expression of tenascin in the mesenchyme. J. Cell Biol. 105: 599-608.

AUSPRUNK, D.H. and FOLKMAN, J. (1977). Migration and proliferation of endothelia cells in preformed and newly formed blood vessels during tumor angiogenesis. Microvascular Research 14: 53-65.

BAAS, P. (1997). Microtubules and axonal growth. Curr. Opin. Cell Biol. 9: 29-36.

BARNES, A.P. and POLLEUX, F. (2009). Establishment of Axon-Dendrite Polarity in Developing Neurons. Annu. Rev. Neurosci. 32: 347-381.

BECCHETTI, E., EVANGELISTI, R., STABELLINI, G., PAGLIARINI, A., BORRELLO, E.D., CALASTRINI, C. and CARINCI, P. (1988). Developmental heterogeneity of mesenchymal glycosaminoglycans (GAG) distribution in chick embryo lung anlagen. Am. J. Anat. 181: 33-42.

BELLUSCI, S., GRINDLEY, J., EMOTO, H., ITOH, N. and HOGAN, B.L. (1997). Fibroblast growth factor 10 (FGF10) and branching morphogenesis in the embryonic mouse lung. Development 124: 4867-78.

BILIMORIA, P.M. and BONNI, A. (2011). Molecular Control of Axon Branching. Neuroscientist 19: 16-24

BIRD, A.D. and CUNTZ, H. (2016). Optimal Current Transfer in Dendrites. PLoS Comp. Biol. 12: e1004897.

BOVE, M., MASSOBRIO, G., MARTINOIA, S. and GRATTAROLA, M. (1994). Realistic simulations of neurons by means of an ad hoc modified version of SPICE. Biol. Cybernet. 71: 137-145.

BURRI, P.H. and TAREK, M.R. (1990). A novel mechanism of capillary growth in the rat pulmonary microcirculation. Anat. Rec. 228: 35-45.

CAMPBELL, K. and GÖTZ, M. (2002). Radial glia: multi-purpose cells for vertebrate brain development. Trends Neurosci. 25: 235-238.

CARDY, J. and TÄUBER, U.C. (1996). Theory of Branching and Annihilating Random Walks. Physical Rev. Lett. 77: 4780-4783.

CELLIERE, G., MENSHYKAU, D. and IBER, D. (2012). Simulations demonstrate a simple network to be sufficient to control branch point selection, smooth muscle and vasculature formation during lung branching morphogenesis. Biology Open 1: 775-788. 
DASEN, J.S. (2009). Chapter 4 Transcriptional Networks in the Early Development of Sensory-Motor Circuits. In Curr. Top. Dev. Biol. (ed., pp. 119-148: Elsevier.

DEUCHAR, E.M. (1975). Cellular Interactions In Animal Development. Thomson Learning.

DEVERMAN, B.E. and PATTERSON, P.H. (2009). Cytokines and CNS development. Neuron 64: 61-78.

DIAZ-HERNANDEZ, M., DEL PUERTO, A., DIAZ-HERNANDEZ, J.I., DIEZ-ZAERA, M., LUCAS, J.J., GARRIDO, J.J. and MIRAS-PORTUGAL, M.T. (2008). Inhibition of the ATP-gated P2X7 receptor promotes axonal growth and branching in cultured hippocampal neurons. J. Cell. Sci. 121: 3717-3728.

DJONOV, V., BAUM, O. and BURRI, P.H. (2003). Vascular remodeling by intussusceptive angiogenesis. Cell Tissue Res. 314: 107-117.

DRINJAKOVIC, J., JUNG, H., CAMPBELL, D.S., STROCHLIC, L., DWIVEDY, A. and HOLT, C.E. (2010). E3 Ligase Nedd4 Promotes Axon Branching by Downregulating PTEN. Neuron 65: 341-357.

EKBLOM, P. (1981). Shift in collagen type as an early response to induction of the metanephric mesenchyme. J. Cell. Biol. 89: 276-283.

EKBLOM, P., ALITALO, K., VAHERI, A., TIMPL, R. and SAXEN, L. (1980). Induction of a basement membrane glycoprotein in embryonic kidney: possible role of laminin in morphogenesis. Proc. Natl. Acad. Sci. USA 77: 485-489.

ELAGHA, E., HEROLD, S., ALAM, D.A., QUANTIUS, J., MACKENZIE, B., CARRARO, G., MOISEENKO, A., CHAO, C.M., MINOO, P., SEEGER, W. et al., (2013). Fgf10positive cells represent a progenitor cell population during lung development and postnatally. Development 141: 296-306

ELLIOTT, H., FISCHER, R.S., MYERS, K.A., DESAI, R.A., GAO, L., CHEN, C.S., ADELSTEIN, R.S., WATERMAN, C.M. and DANUSER, G. (2015). Myosin ॥ controls cellular branching morphogenesis and migration in three dimensions by minimizing cell-surface curvature. Nature Cell Biol. 17: 137-147.

ETTENSOHN, C.A. (1985). Mechanisms of Epithelial Invagination. Quart. Rev. Biol. 60: 289-307.

FLYNN, K.C., STIESS, M. and BRADKE, F. (2013). Role of the Cytoskeleton and Membrane Trafficking in Axon-Dendrite Morphogenesis. In Cellular Migration and Formation of Neuronal Connections, (eds. Rubenstein, J.L.R. and Rakic, P.) pp. 19-50. Elsevier.

FUJISHIMA, K., HORIE, R., MOCHIZUKI, A. and KENGAKU, M. (2012). Principles of branch dynamics governing shape characteristics of cerebellar Purkinje cell dendrites. Development 139: 3442-3455.

FUKUDA, Y., MASUDA, Y., KISHI, J., HASHIMOTO, Y., HAYAKAWA, T., NOGAWA, H. and NAKANISHI, Y. (1988). The role of interstitial collagens in cleft formation of mouse embryonic submandibular gland during initial branching. Development 103: 259-67.

GHABRIAL, A., LUSCHNIG, S., METZSTEIN, M.M. and KRASNOW, M.A. (2003). Branching Morphogenesis of the Drosophila Tracheal System. Ann. Rev. Cell Dev. Biol. 19: 623-647.

GHABRIAL, A.S. and KRASNOW, M.A. (2006). Social interactions among epithelial cells during tracheal branching morphogenesis. Nature 441: 746-749.

GIBSON, D.A. and MA, L. (2011). Developmental regulation of axon branching in the vertebrate nervous system. Development 138: 183-195

GJOREVSKI, N. and NELSON, C.M. (2011). Integrated morphodynamic signalling of the mammary gland. Nature Rev. Molec. Cell Biol. 12: 581-593.

GOLDIN, G.V. (1980). Towards a mechanism for morphogenesis in epithelio-mesenchymal organs. Quart Rev Biol 55: 251-65.

GOLOSOW, N. and GROBSTEIN, C. (1962). Epitheliomesenchymal interaction in pancreatic morphogenesis. Dev. Biol. 4: 242-255.

GOTZ, M. and HUTTNER, W.B. (2005). The cell biology of neurogenesis. Nat Rev Mol Cell Biol 6: 777-88.

GROBSTEIN, C. (1953). Analysis in vitro of the early organization of the rudiment of the mouse submandibular gland. J. Morphol. 93: 19-43.

GROBSTEIN, C. (1954). Tissue interaction in the morphogenesis of mouse embryonic rudiments in vitro. In Aspects of Synthesis and Order in Growth. (ed. Rudnick, D.) pp. 223-256, Princeton University Press.

GROBSTEIN, C. (1955). Tissue disaggregation in relation to determination and stability of cell type. Ann. N.Y. Acad. Sci. 60: 1095-1107.

GROBSTEIN, C. (1956). Inductive Tissue Interaction in Development. Advances Cancer Res. 4: 187-236.
GROBSTEIN, C. (1967). Mechanisms of organogenetic tissue interaction. Natl Cancer Inst Monogr 26: 279-99.

GROVE, E.A. and MONUKI, E.S. (2013). Morphogens, Patterning Centers, and their Mechanisms of Action. In Patterning and Cell Type Specification in the Developing CNS and PNS, (eds. Rubenstein, J.L.R. and Rakic, P.). pp. 25-44: Elsevier.

GROVER, J.W. (1961a). The enzymatic dissociation and reproducible reaggregation in vitro of 11-day embryonic chick lung. Dev. Biol. 3: 555-568.

GROVER, J.W. (1961b). The relation between the embryonic age of dissociated chick lung cells and their capacity for reaggregation and histogenesis in vitro. Exp. Cell Res. 24: 171-173.

GUIDOLIN, D., CRIVELLATO, E. and RIBATTI, D. (2011). The "self-similarity logic" applied to the development of the vascular system. Dev. Biol. 351: 156-162.

GUIDOLIN, D., FEDE, C. and TORTORELLA, C. (2018). Nerve cells developmental processes and the dynamic role of cytokine signaling. Int. J. Dev. Neurosci.77: 3-17.

GUIDOLIN, D., TORTORELLA, C., DE CARO, R. and AGNATI, L.F. (2016). Does a Self-Similarity Logic Shape the Organization of the Nervous System? In The fractal geometry of the brain (ed. Di Leva, A) pp. 137-156. Springer, New York.

GUIDOLIN, D., VACCA, A., NUSSDORFER, G.G. and RIBATTI, D. (2004). A new image analysis method based on topological and fractal parameters to evaluate the angiostatic activity of docetaxel by using the Matrigel assay in vitro. Microvasc. Res. 67: 117-124.

HALL, A. and LALLI, G. (2010). Rho and Ras GTPases in Axon Growth, Guidance, and Branching. Cold Spring Harbor Persp. Biol. 2: a001818.

HANNEZO, E., SCHEELE, C.L.G.J., MOAD, M., DROGO, N., HEER, R., SAMPOGNA, R.V., VAN RHEENEN, J. and SIMONS, B.D. (2017). A Unifying Theory of Branching Morphogenesis. Cell 171: 242-255.e27.

HANNEZO, E. and SIMONS, B.D. (2018). Statistical theory of branching morphogenesis. Dev Growth Differ 60: 512-521.

HARTMANN, D. and MIURA, T. (2006). Modelling in vitro lung branching morphogenesis during development. J. Theor. Biol. 242: 862-872.

HATAKEYAMA, J. (2004). Hes genes regulate size, shape and histogenesis of the nervous system by control of the timing of neural stem cell differentiation. Development 131: 5539-5550.

HELLSTRÖM, M., PHNG, L.-K., HOFMANN, J.J., WALLGARD, E., COULTAS, L., LINDBLOM, P., ALVA, J., NILSSON, A.-K., KARLSSON, L., GAIANO, N. et al., (2007). DII4 signalling through Notch1 regulates formation of tip cells during angiogenesis. Nature 445: 776-780.

HILLMAN, D. (1988). Parameters of dendritic shape and substructure: Intrinsic and extrinsic determination. In Intrinsic determinants of neuronal form and function. (Eds. Laske RJ, Black, MM) pp. 83-113, New York. Alan R. Liss.

HOGAN, B.L.M. and KOLODZIEJ, P.A. (2002). Molecular Mechanisms Of Tubulogenesis. Nature Rev. Genet. 3: 513-523.

HOWARD, M.J. and TAUBER U.C. (1997). Universality in Two Classes of Reaction-Diffusion Systems. arXiv preprint cond-mat/9701069.

HUEBNER, R.J., NEUMANN, N.M. and EWALD, A.J. (2016). Mammary epithelial tubes elongate through MAPK-dependent coordination of cell migration. J. Cell Sci. 129: e1.1.

IBER, D. and MENSHYKAU, D. (2013). The control of branching morphogenesis. Open Biol. 3: 130088.

IONESCU, C., OUSTALOUP, A., LEVRON, F., MELCHIOR, P., SABATIER, J. and DE KEYSER, R. (2009). A Model of the Lungs Based on Fractal Geometrical and Structural Properties. IFAC Proc. Volumes 42: 994-999.

JAKOBSSON, L., FRANCO, C.A., BENTLEY, K., COLLINS, R.T., PONSIOEN, B., ASPALTER, I.M., ROSEWELL, I., BUSSE, M., THURSTON, G., MEDVINSKY, A. et al., (2010). Endothelial cells dynamically compete for the tip cell position during angiogenic sprouting. Nature Cell Biol. 12: 943-953.

JONES, D.M., TUCKER, B.A., RAHIMTULA, M. and MEAROW, K.M. (2003). The synergistic effects of NGF and IGF-1 on neurite growth in adult sensory neurons: convergence on the PI 3-kinase signaling pathway. J. Neurochem. 86: 1116-1128.

JU, H., HINES, M.L. and YU, Y. (2016). Cable energy function of cortical axons. Sci. Rep. 6: 29686.

KALIL, K. and DENT, E.W. (2013). Branch management: mechanisms of axon branching in the developing vertebrate CNS. Nature Rev. Neurosci. 15: 7-18.

KASHIMATA, M. and GRESIK, E.W. (1997). Epidermal growth factor system is a physiological regulator of development of the mouse fetal submandibular gland 
and regulates expression of the $\alpha$ 6-integrin subunit. Dev. Dynamics 208: 149-161. KIM, HYE Y., PANG, M.-F., VARNER, VICTORD., KOJIMA, L., MILLER, E., RADISKY, DEREK C. and NELSON, CELESTE M. (2015). Localized Smooth Muscle Differentiation Is Essential for Epithelial Bifurcation during Branching Morphogenesis of the Mammalian Lung. Dev. Cell 34: 719-726.

KOLLINS, K.M. and DAVENPORT, R.W. (2005). Branching Morphogenesis in Vertebrate Neurons. In Branching Morphogenesis, (ed. Davies, J.A.) pp. 8-65: Springer US.

KRATOCHWIL, K. (1969). Organ specificity in mesenchymal induction demonstrated in the embryonic development of the mammary gland of the mouse. Dev. Biol. 20: 46-71.

KUME, T. (2009). Novel insights into the differential functions of Notch ligands in vascular formation. J. Angiogen. Res. 1: 8.

LANG, C., CONRAD, L. and MICHOS, O. (2018). Mathematical Approaches of Branching Morphogenesis. Frontiers Genet. 9: 673.

LE NOBLE, F. (2003). Flow regulates arterial-venous differentiation in the chick embryo yolk sac. Development 131: 361-375.

LIVET, J., SIGRIST, M., STROEBEL, S., DE PAOLA, V., PRICE, S.R., HENDERSON, C.E., JESSELL, T.M. and ARBER, S. (2002). ETS Gene Pea3 Controls the Central Position and Terminal Arborization of Specific Motor Neuron Pools. Neuron 35: 877-892.

LOFFREDO SAMPAOLO, C. and SAMPAOLO, G. (1961). Indagini sperimentali sullo sviluppo del polmone embrionale (pollo e coniglio). Quaderni di Anatomia Pratica 17: 1-43.

LU, P. and WERB, Z. (2008). Patterning mechanisms of branched organs. Science 322: 1506-9.

LUBARSKY, B. and KRASNOW, M.A. (2003). Tube Morphogenesis. Cell 112: 19-28.

LUBKIN, S.R. and MURRAY, J.D. (1995). A mechanism for early branching in lung morphogenesis. J. Mathemat. Biol. 34: 77-94.

MACIAS, H. and HINCK, L. (2012). Mammary gland development. Wiley Interdisciplinary Reviews: Dev. Biol. 1: 533-557.

MANOR, Y., GONCZAROWSKI, J. and SEGEV, I. (1991). Propagation of action potentials along complex axonal trees. Model and implementation. Biophys. J. 60: 1411-1423.

MCATEER, J.A., EVAN, A.P. and GARDNER, K.D. (1987). Morphogenetic clonal growth of kidney epithelial cell line MDCK. Anat. Rec. 217: 229-239.

MEDELNIK, J.-P., ROENSCH, K., OKAWA, S., DELSOL, A., CHARA, O., MCHEDLISHVILI, L. and TANAKA, E.M. (2018). Signaling-Dependent Control of Apical Membrane Size and Self-Renewal in Rosette-Stage Human Neuroepithelial Stem Cells. Stem Cell Rep. 10: 1751-1765.

MEINHARDT, H. (1982). Models of Biological Pattern Formation (Citeseer). Academic Press, London.

MENSHYKAU, D. and IBER, D. (2013). Kidney branching morphogenesis under the control of a ligand-receptor-based Turing mechanism. Phys. Biol. 10: 046003.

METZGER, R.J., KLEIN, O.D., MARTIN, G.R. and KRASNOW, M.A. (2008). The branching programme of mouse lung development. Nature 453: 745-750.

MITCHISON, G. (1991). Neuronal branching patterns and the economy of cortical wiring. Proc Biol Sci 245: 151-8.

MONTESANO, R., ORCI, VASSALLI, P. (1983). In vitro rapid organization of endothelial cells into capillary-like networks is promoted by collagen matrices. J. Cell. Biol. 97: 1648-1652.

MONTESANO, R., SOLULIE, P., CARROZZINO, F., (2005). Tumour necrosis factor confers an invasive, transformed phenotype on mammary epithelial cells. J. Cell. Sci. 118: 3487-3500.

MONTESANO, R. (2007). Bone morphogenetic protein-4 abrogates lumen formation by mammary epithelial cells and promotes invasive growth. Biochem. Biophys. Res. Comm. 353: 817-822.

MONTESANO, R., CARROZZINO, F. and SOULIÉ, P. (2007). Low concentrations of transforming growth factor-beta-1 induce tubulogenesis in cultured mammary epithelial cells. BMC Dev. Biol. 7: 7 .

MONTESANO, R., MATSUMOTO, K., NAKAMURA, T. and ORCI, L. (1991a). Identification of a fibroblast-derived epithelial morphogen as hepatocyte growth factor. Cell 67: 901-908.

MONTESANO, R. and ORCI, L. (1985). Tumor-promoting phorbol esters induce angiogenesis in vitro. Cell 42: 469-477

MONTESANO, R., SCHALLER, G. and ORCI, L. (1991b). Induction of epithelial tubular morphogenesis in vitro by fibroblast-derived soluble factors. Cell 66: 697-711.

MONTESANO, R. and SOULIE, P. (2002). Retinoids induce lumen morphogenesis in mammary epithelial cells. J Cell Sci 115: 4419-31.

MONTESANO, R., VASSALLI, J.D., BAIRD, A., GUILLEMIN, R. and ORCI, L. (1986). Basic fibroblast growth factor induces angiogenesis in vitro. Proc. Natl. Acad. Sci. USA 83: 7297-7301.

MORI, H., GJOREVSKI, N., INMAN, J.L., BISSELL, M.J. and NELSON, C.M. (2009). Self-organization of engineered epithelial tubules by differential cellular motility. Proc. Natl. Acad. Sci. USA 106: 14890-14895.

MORI, H., LO, A.T., INMAN, J.L., ALCARAZ, J., GHAJAR, C.M., MOTT, J.D., NELSON, C.M., CHEN, C.S., ZHANG, H., BASCOM, J.L. et al., (2012). Transmembrane/ cytoplasmic, rather than catalytic, domains of Mmp14 signal to MAPK activation and mammary branching morphogenesis via binding to integrin 1. Development 140: 343-352.

NAKANISHI, Y., NOGAWA, H., HASHIMOTO, Y., KISHI, J. and HAYAKAWA, T. (1988). Accumulation of collagen III at the cleft points of developing mouse submandibular epithelium. Development 104: 51-9.

NELSON, T.R., WEST, B.J. and GOLDBERGER,A.L. (1990). The fractal lung: Universa and species-related scaling patterns. Experientia 46: 251-254.

NOGAWA, H. and ITO, T. (1995). Branching morphogenesis of embryonic mouse lung epithelium in mesenchyme-free culture. Development 121: 1015-22.

NOGUERA-TROISE, I., DALY, C., PAPADOPOULOS, N.J., COETZEE, S., BOLAND, P., GALE, N.W., LIN, H.C., YANCOPOULOS, G.D. and THURSTON, G. (2006). Blockade of DII4 inhibits tumour growth by promoting non-productive angiogenesis. Nature 444: 1032-7.

OFER, N., SHEFI, O. and YAARI, G. (2017). Branching morphology determines signal propagation dynamics in neurons. Sci. Rep. 7: 8877.

PARK, W.Y., MIRANDA, B., LEBECHE, D., HASHIMOTO, G. and CARDOSO, W.V. (1998). FGF-10 Is a Chemotactic Factor for Distal Epithelial Buds during Lung Development. Dev. Biol. 201: 125-134.

PEIRCE, S. and SKALAK, T.C. (2003). Microvascular Remodeling: A Complex Continuum Spanning Angiogenesis to Arteriogenesis. Microcirc. 10: 99-111.

PEPPER, M.S., FERRARA, N., ORCI, L. and MONTESANO, R. (1992a). Potent synergism between vascular endothelial growth factor and basic fibroblast growth factor in the induction of angiogenesis in vitro. Biochem. Biophys. Res. Comm. 189: 824-831.

PEPPER, M.S., MATSUMOTO, K., NAKAMURA, T., ORCI, L. and MONTESANO, R. (1992b). Hepatocyte growth factor increases urokinase-type plasminogen activator (u-PA) and u-PA receptor expression in Madin-Darby canine kidney epithelia cells. J Biol Chem 267: 20493-6.

PEPPER, M.S., SORIANO, J.V., MENOUD, P.-A., SAPPINO, A.-P., ORCI, L. and MONTESANO, R. (1995). Modulation of Hepatocyte Growth Factor and c-met in the Rat Mammary Gland during Pregnancy, Lactation, and Involution. Exp. Cell Res. 219: 204-210.

PEPPER, M.S., VASSALLI, J.D., MONTESANO, R. and ORCI, L. (1987). Urokinasetype plasminogen activator is induced in migrating capillary endothelial cells. $J$ Cell Biol 105: 2535-41.

POLLEUX, F. (2013). Development of Neuronal Polarity In Vivo. In Cellular Migration and Formation of Neuronal Connections, (eds. Rubenstein, J.L.R. and Rakic, P.) pp. 3-18: Elsevier.

PORZIONATO, A., GUIDOLIN, D., MACCHI, V., SARASIN, G., GRISAFI, D., TORTORELLA, C., DEDJA, A., ZARAMELLA, P. and DE CARO, R. (2016). Fractal analysis of alveolarization in hyperoxia-induced rat models of bronchopulmonary dysplasia. Am. J. Physi. -Lung Cellular and Molecular Physiology310: L680-L688.

RICCIO, P., CEBRIAN, C., ZONG, H., HIPPENMEYER, S. and COSTANTINI, F. (2016). Ret and Etv4 Promote Directed Movements of Progenitor Cells during Renal Branching Morphogenesis. PLoS Biology 14: e1002382.

RISAU, W. (1997). Mechanisms of angiogenesis. Nature 386: 671-674

ROMAN, J. (1997). Fibronectin and Fibronectin Receptors in Lung Development. Exp. Lung Res. 23: 147-159.

RUBENSTEIN, J.L.R. and RAKIC, P. (2013). Introduction to Comprehensive Developmental Neuroscience. In Patterning and Cell Type Specification in the Developing CNS and PNS, (eds. Rubenstein, J.L.R. and Rakic, P.) pp. xiii: Elsevier. 
RUDNICK, D. (1933). Developmental capacities of the chick lung in chorioallantoic grafts. J. Exp. Zool. 66: 125-153.

SAKAI, T., LARSEN, M. and YAMADA, K.M. (2003). Fibronectin requirement in branching morphogenesis. Nature 423: 876-881.

SAKAKURA, T. (1991). New aspects of stroma-parenchyma relations in mammary gland differentiation. Int Rev Cytol 125: 165-202.

SARIOLA, H., EKBLOM, P. and SAXEN, L. (1982). Restricted developmental options of the metanephric mesenchyme. Prog Clin Biol Res 85 Pt B: 425-31.

SASAKI, T., MATSUKI, N. and IKEGAYA, Y. (2011). Action-Potential Modulation During Axonal Conduction. Science 331: 599-601.

SASAKI, T., MATSUKI, N. and IKEGAYA, Y. (2012). Effects of Axonal Topology on the Somatic Modulation of Synaptic Outputs. J. Neurosci. 32: 2868-2876.

SAXEN, L. (1987). Organogenesis of the Kidney. Cambridge University Press.

SAXÉN, L. (1970). Failure to demonstrate tubule induction in a heterologous mesenchyme. Dev. Biol. 23: 511-523.

SHAKYA, R., WATANABE, T. and COSTANTINI, F. (2005). The Role of GDNF/Ret Signaling in Ureteric Bud Cell Fate and Branching Morphogenesis. Dev. Cell8: 65-74.

SHANNON, J.M. (1994). Induction of Alveolar Type II Cell Differentiation in Fetal Tracheal Epithelium by Grafted Distal Lung Mesenchyme. Dev. Biol. 166:600-614.

SHELLY, M., CANCEDDA, L., HEILSHORN, S., SUMBRE, G. and POO, M.-M. (2007). LKB1/STRAD Promotes Axon Initiation During Neuronal Polarization. Cell 129: 565-577.

SORIANO, J.V., ORCI, L. and MONTESANO, R. (1996). TGF- $\beta 1$ Induces Morphogenesis of Branching Cords by Cloned Mammary Epithelial Cells at Subpicomolar Concentrations. Biochem. Biophys. Res. Comm. 220: 879-885.

SORIANO, J.V., PEPPER, M.S., NAKAMURA, T., ORCI, L. and MONTESANO, R. (1995). Hepatocyte growth factor stimulates extensive development of branching duct-like structures by cloned mammary gland epithelial cells. J Cell Sci 108 (Pt 2): 413-30.

SPOONER, B.S. and WESSELLS, N.K. (1970). Mammalian lung development: Interactions in primordium formation and bronchial morphogenesis. J. Exp. Zool. 175: $445-454$.
STOCKBRIDGE, N. (1988). Differential conduction at axonal bifurcations. II. Theoretical basis. J. Neurophysiol. 59: 1286-1295.

STOCKBRIDGE, N. and STOCKBRIDGE, L.L. (1988). Differential conduction at axonal bifurcations. I. Effect of electrotonic length. J. Neurophysiol. 59: 1277-1285.

SUCHTING, S., FREITAS, C., LE NOBLE, F., BENEDITO, R., BREANT, C., DUARTE A. and EICHMANN, A. (2007). The Notch ligand Delta-like 4 negatively regulates endothelial tip cell formation and vessel branching. Proc. Natl. Acad. Sci. USA 104: 3225-3230.

SUTHERLAND, D., SAMAKOVLIS, C. and KRASNOW, M.A. (1996). branchless Encodes a Drosophila FGF Homolog That Controls Tracheal Cell Migration and the Pattern of Branching. Cell 87: 1091-1101.

TANAKA, S. (2015). Simulation Frameworks for Morphogenetic Problems. Computation 3: 197-221.

TURING, A.M. (1952). The chemical basis of morphogenesis.. Philos. Transa. R. Soc. B Biol. Sci. 237: 37-72.

VARNER, V.D. and NELSON, C.M. (2014). Cellular and physical mechanisms of branching morphogenesis. Development 141: 2750-2759.

WATANABE, T. and COSTANTINI, F. (2004). Real-time analysis of ureteric bud branching morphogenesis in vitro. Dev. Biol. 271: 98-108.

WESSELLS, N.K. (1970). Mammalian lung development: Interactions in formation and morphogenesis of tracheal buds. J. Exp. Zool. 175: 455-466.

WILLIAMS, J.M. and DANIEL, C.W. (1983). Mammary ductal elongation: Differentiation of myoepithelium and basal lamina during branching morphogenesis. Dev. Biol. 97: 274-290.

YI, J.J., BARNES, A.P., HAND, R., POLLEUX, F. and EHLERS, M.D. (2010). TGF- $\beta$ Signaling Specifies Axons during Brain Development. Cell 142: 144-157.

YU, J., CARROLL, T.J., RAJAGOPAL, J., KOBAYASHI, A., REN, Q. and MCMAHON, A.P. (2008). A Wnt7b-dependent pathway regulates the orientation of epithelia cell division and establishes the cortico-medullary axis of the mammalian kidney. Development 136: 161-171.

ZHAO, H., KEGG, H., GRADY, S., TRUONG, H.-T., ROBINSON, M.L., BAUM, M and BATES, C.M. (2004). Role of fibroblast growth factor receptors 1 and 2 in the ureteric bud. Dev. Biol. 276: 403-415. 


\section{Further Related Reading, published previously in the Int. J. Dev. Biol.}

Prep1 (pKnox1) transcription factor contributes to pubertal mammary gland branching morphogenesis Lara Sicouri, Federica Pisati, Salvatore Pece, Francesco Blasi and Elena Longobardi

Int. J. Dev. Biol. (2018) 62: 827-836

https://doi.org/10.1387/ijdb.180278fb

Early hematopoietic and vascular development in the chick

Hiroki Nagai, Masahiro Shin, Wei Weng, Fumie Nakazawa, Lars Martin Jakt, Cantas Alev and Guojun Sheng

Int. J. Dev. Biol. (2018) 62: 137-144

https://doi.org/10.1387/ijdb.170291gs

Epithelial-mesenchymal interactions: a fundamental Developmental Biology mechanism Domenico Ribatti and Marcello Santoiemma

Int. J. Dev. Biol. (2014) 58: 303-306

https://doi.org/10.1387/ijdb.140143dr

Sox7 in vascular development: review, insights and potential mechanisms Jeanette J. Wat and Margaret J. Wat

Int. J. Dev. Biol. (2014) 58: 1-8

https://doi.org/10.1387/ijdb.130323mw

Modeling of angioadaptation: insights for vascular development

Axel R. Pries, Bettina Reglin and Timothy W. Secomb

Int. J. Dev. Biol. (2011) 55: 399-405

https://doi.org/10.1387/ijdb.103218ap
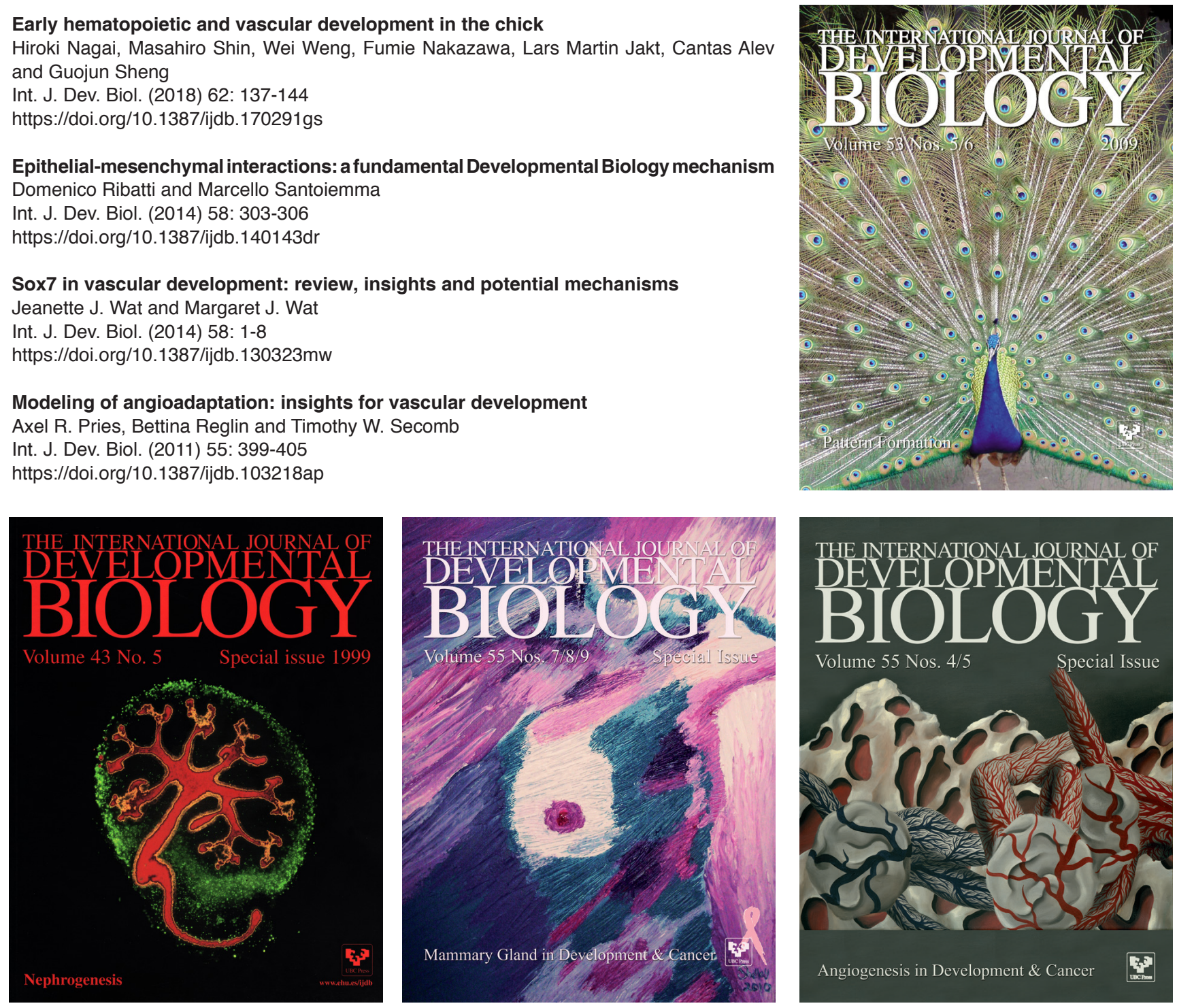